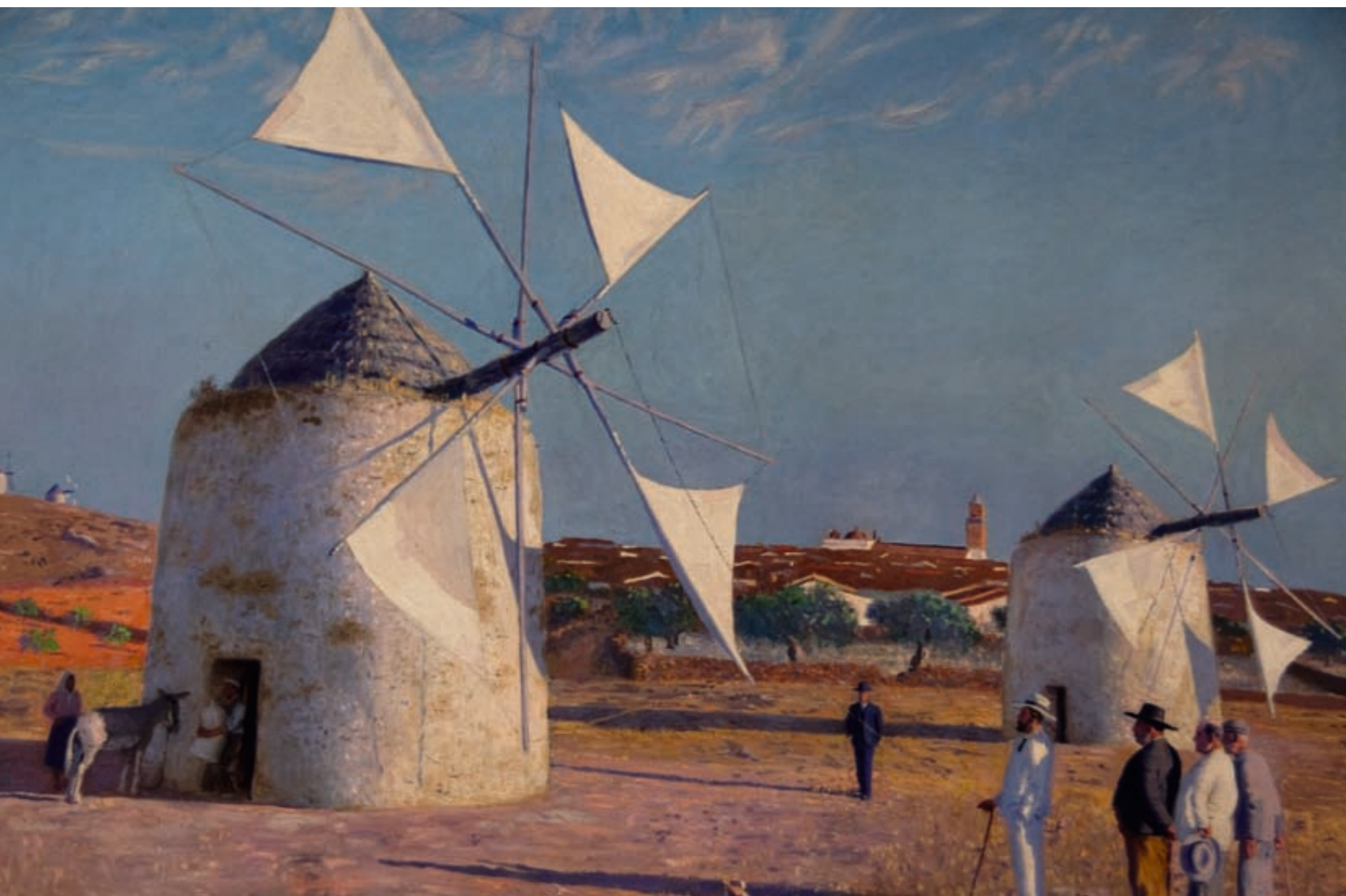

"Molinos que trabajaban en La Puebla de Guzmán hasta aproximadamente el año 1920. Fue pintado en 1950 ya no quedan sino restos." Manuscrito del autor al dorso del lienzo. Sebastián García, 1950. Foto: Aniceto Delgado Méndez, IAPH

\title{
Imagen contemporánea, reelaboraciones del paisaje
}

El territorio geográfico se reivindicará en cada momento para ser un producto distinto. En la línea de los discursos actuales, el espacio no es sino la traslación de un producto social (maneja identidades, transforma usos, genera ansiedades de nueva utilización y pone en valor aquello que parece que está de acuerdo con tendencias, relaciones de género...).

Quizás en la identidad como elemento primordial de la cultura es donde las imágenes que queramos proyectar y fabricar sean el motor más importante. Espacios candidatos a continuos cambios que tratan de hacer visible lo invisible además de atractivo o rentable aquello que va cayendo en desuso.

El arte es, sin duda, un elemento de reelaboración del hecho diferencial y en su caso una especificidad que busca reconocimiento, distinguible de otros, diferente, atractivo, "único". El paisaje ha servido de ventana para expresiones plásticas diversas y creación de ideas. El arte contemporáneo se ha abonado en su plástica de la misma manera que el refuerzo de la identidad en la mirada, sobre todo en la fotografía. Asistimos en estos 15 últimos años a la frecuente in- cursión en temas urbanos, en la (nueva) desintegración de las clases, diversidades en un mismo espacio o rescate de la arqueología industrial.

En la comarca del Andévalo hay una relación de límites con la vecina Portugal (Algarve y Alentejo) y la marca de la minería introduce otras culturas externas y posibilita una burguesía escogida. Paradójico es encontrar en Nerva un Museo de arte contemporáneo (1999) con amplia colección (nueva pintura contemporánea española) que agrupa a un gran número de críticos (Juan $\mathrm{M}$. Bonet), galeristas (Juana de Aizpuru) o artistas (Quico Rivas), que elaboran relaciones con el paisaje en esta y otras comarcas limitrofes, aunque para la identificación señalética y como entrada del pueblo es la torre erguida, el malacate minero quien nos recibe.

Pero también existe un riesgo hacia la tematización y homogenización al clonar imágenes reconocibles y que contradice su pretendida unicidad creando aterritorialidad. Un buen ejemplo es la incorporación de nuevos elementos escultóricos (escultura para el lugar), además de los monumentales, para definir nuevas exigencias en la distribución espacial.
Objetos decorando rotondas o hitos arquitectónicos casi escultóricos (nuevo puente sobre el Guadiana). Referentes escultóricos identitarios realizados en los últimos años (las danzas en San Bartolomé de la Torre o el cante flamenco en Alosno, busto a Paco Toronjo) al igual que en otras zonas y poblaciones.

Prácticas artísticas reveladoras y sorprendentes inciden en este espacio por su importancia como el Museo de Aracena, con más de cuarenta y tres esculturas de autores contemporáneos bajo el proyecto del escultor Pepe Noja en 1972, pionero en España junto con el de la Castellana en Madrid.

Además se está releyendo las vivencias de espacios de sociabilidad con nuevas apropiaciones. El arte, además de documentar estos elementos como sucesión de hechos, propone la diferencia en la mirada; sin duda es ésta la que reelabora el paisaje.

José Carlos Roldán Saborido

Conservador del Centro Andaluz de Arte Contemporáneo 